\title{
Shaanxi Higher Education Foundation status and characteristics analysis
}

\author{
Shuaihong Wang ${ }^{1,}$, Kangmei Wang ${ }^{2, b}$ \\ ${ }^{1}$ Xi'an International University, Xi'an, Shaanxi, 710077 \\ ${ }^{a}$ email
}

Keywords: Private Education, Foundation Universities, Operating Characteristics

\begin{abstract}
Private College Education Foundation develops slowly, has restricted the development of universities in shackles. This paper analyzes the characteristics of China's Higher Education Development Foundation to start, the basic situation of the specific research and operational quality of college and Education Foundation of Shaanxi Province, Shaanxi summed Private University Education Foundation presents donation income and expenditure is extremely uneven, professional relatively scarce management talent, the smaller scale of development, organization and management mechanism is not perfect specification, and high transparency is generally not called for government attention to the development of education and universities Foundation.
\end{abstract}

\section{Introduction}

Education Foundation in our country's development and construction of only a few dozen years, though to China's education has made a significant contribution, but in today's colleges and universities in transition, regardless of the number of sources and uses of funds of funds, or foundations policy mechanisms are still many problems to be solved exist live. Especially in private education Colleges Foundation develops slowly, has restricted the development of China's Private Colleges in shackles. Eighth session of the Fourth Plenary Session was held and the "decision to accelerate the development of modern vocational education," the State Department, once again sounded the weight of deepening education reform, the CPC Central Committee asked us to greater wisdom and courage to seize the opportunity to deepen reform, reform is the driving force and source of all the world development of things, the reform is to continue exploration and innovation, and to explore the area is to challenge and break through the taboo, innovation is to break through the barriers to seek new development, the Task force believes that the issue of Private Higher Education development Fund We should also take on this attitude, following a few remarks about the problem to start a discussion.

\section{The Characteristics of Chinese Higher Education Development Foundation}

2014 National Private Colleges Universities ordinary share reached 19.77 percent, higher education has become an important force in China's development can not be ignored. However, private education Universities Foundation has developed very slow, difficult to resolve in private colleges and universities to improve teaching and research quality funding needs, the problem is very serious.

First, let us from the national perspective of comparative analysis of the two data sets. A set of data is the data of Private Colleges and Universities, another set of data is the National Education Foundation data. According to the Ministry of Education website for information, as of July 2014, there were colleges and universities (excluding Independent Institute) 2542, wherein: 2246 universities and colleges (including private colleges and universities 444); 296 adult colleges and universities. According to the China Foundation Center website CFC industry data, as of October 2014 the number of the National Foundation for 4024, of which 1474 private foundations, private foundations 2550. From the use of the Fund, the National Education Foundation, a total of 1928, the Foundation organized in the form of Chinese education is becoming effective mobilization of social resources. According to the same source, there are 436 colleges and universities established 
education foundation. Based on the above statistics calculations, the number of National Education Foundation accounted for $47.9 \%$ of the Foundation, it seems that the proportion is not too low; but if the Education Foundation of the College Education Foundation compared with the number of colleges and universities, you will find this ratio very low - the total amount of the University educational Foundation of the National College quantity less than $17.1 \%$, indicating that much of the total of the University educational Foundation, in other words our Education Foundation has developed rapidly, but in our higher education role-playing is not heavy weight.

If we further research and analysis about the Chinese University Educational Foundation data, you will find another interesting phenomenon, that is, within 436 College Foundation, both the absorption amount of social capital or net assets of the Fund balance and geographical distribution follow the "Pareto rule." According to the Foundation Center data show that a total of 38985 Colleges Foundation, the National Higher Education Fund accounted for only 8.7\% of 436, 985 College Foundation, but eye-catching gold absorption capacity, 985 donated income in 2013 was 4.9 billion yuan College Foundation College Foundation donated the total income of 7.2 billion yuan almost 70. It is particularly worth mentioning is that, in 4.9 billion yuan, the Tsinghua University, Peking University Education Foundation and Education Foundation donated revenue only two foundations accounted for $58 \%$ of all 985 College Foundation donated revenue. In addition, Tsinghua University, Peking University Education Foundation and Education Foundation, the third largest, four or five are: Education Foundation, Zhejiang University, Beijing University of Aeronautics and Astronautics and Education Foundation Education Development Foundation, Shanghai Jiaotong University. In addition, from the amount of the net assets of the Foundation Universities can also see this trend, 985 College Foundation net assets have been expanding, from \$ 2.4 billion in 2009, the rapid growth in 2013 of 7.8 billion yuan, accounting for College Foundation about half of the total net assets of 15.8 billion yuan, Tsinghua University, Peking University, Zhejiang University, three universities Foundation net assets among the top three mainland Foundation. In accordance with the number of college rankings Foundation, with 134 colleges and universities in Jiangsu Province to 91 the total number of mainland ranked first, while the number of Shaanxi Province has 80 colleges and universities in the number of college foundation came in twenty-eight.

\section{The Basic Situation and Operating Quality of Education Foundation in Universities in Shaanxi}

According to the data in July 2014 College Ministry of Education website for the latest number of colleges and universities in Shaanxi Province have 80, but the number of Shaanxi Province Education Fund is very small, according to the China Foundation Center CFC message, Shaanxi total of 35 foundations, including Education accounted for 25 funds, of which about 10\% of semi-official nature, such as the development Fund for UNESCO Yan'an, Xianyang Qindu District educational development Foundation. In Higher Education Fund Education Fund only 15, ranked number 28 in the country, and ranked first in Jiangsu Province far. If the design and calculation of the number of University College Foundation and the ratio of the number of indicators to measure, we will find that $18.75 \%$ of Shaanxi Province, Jiangsu Province and 68\%, a difference of 3.6 times the two provinces. Also from the issuer way to see outside except through the Xi'an Jiaotong University Foundation and a few other foundations belong to the nature of local private foundations, colleges and universities in Shaanxi Province Education Foundation majority belong to the nature of private equity funds, the Foundation is not public offering or private offering, That is a particular minority investors as a target issue, the issue basic there are two types: one is closely associated with the school or relationships of specific companies or individuals, and second, certain institutional funds and institutional investors. Our group of its operation is through their website one by one to read it to understand the public disclosure of information, now finishing its analysis as follows:

Northwest Polytechnical University Education Foundation is approved by the Shaanxi Provincial Department of Civil Affairs, a non-profit social organization in May 2007 formally established. 
Audit reports from the school to see the Foundation's Web site disclosure, the Foundation donated revenue in 2012 reached a record peak of 143 million yuan, the Foundation currently running well, and the other in February 2015, according to the China Foundation Center website CFC industry statistics, the Foundation net assets ranked first in Shaanxi Education Fund, the net assets had reached 190.06 million yuan.

Xi'an Jiaotong University Education Foundation, a local private foundations, the Foundation aims to mobilize all social forces and rely extensively for domestic and foreign organizations and individuals concerned about the contributions of higher education in western China development, supporting technological innovation and personnel training, It supports the creation of world-renowned universities. Audit reports from the site http://www.ef.xjtu.edu.cn/ data disclosed, the 2012, 2013 The Foundation accepts donations funds were 32.28 million yuan, 35.35 million yuan in 2014 exceeded one hundred million.

Education of Shaanxi Normal University Foundation, is approved by the Shaanxi Provincial Department of Education, the Shaanxi Provincial Department of Civil Affairs for registration of private foundations, in September 2011 was formally established, its URL http://alu.snnu.edu.cn/ Disclosure report data, in 2012, Shaanxi Normal Education Foundation accepts donations 23,620,000 yuan, 2013 annual donations 8.08 million yuan. Major lines of business: social acceptance of voluntary donations; to strengthen ties and cooperation with all sectors outside the territory; raise law, management and operation of the Fund; carry out special financing incentives and other activities. Donated funds purposes: student grants, teacher development, school construction, environmental protection and energy saving, celebration.

Northwest Agriculture and Forestry University of Science and Education Development Foundation, although established in 2011, but the development of fast and regular management, reporting data from its website http://jjh.chd.edu.cn disclosure shows that the total number of its income from donations received for 2013 to 11.619 million yuan, net assets of 29.11 million yuan, and its investment banking income 46,308 yuan. By the China Foundation for industry assessment, CFC will be listed as the National Education Foundation College 2013 annual data transparency highest top five, also the first in Shaanxi Province College Foundation transparency.

Xi'an University of Electronic Science and Technology Education Foundation, the report found that data from its disclosure, Xi'an University of Electronic Science and Technology Education Foundation in 2012 to accept the donated 4.56 million yuan, 8.64 million yuan in 2013 to accept donations, by the end of 2013 the net assets exceeded 9.37 million yuan. The main campus for the construction of infrastructure and supporting facilities, scholarships, grants and research grants, awards and funding for students and teachers, and to carry out other education-related social welfare activities, teacher development and funding, the anniversary celebration activities, subscribe " alumni newsletter "magazine, support local alumni association, the implementation of the project in accordance with the wishes of the donors, to support activities and projects of other beneficial development of the school.

Chang'an University Education Fund from its website http://jjh.chd.edu.cn report data disclosed, the 2013 donations of funds 2.02 million yuan. Business: to accept donations, management and use of funds to carry out incentives, financing activities and provide training and technical consulting. Use of donated funds: Student training, construction of teachers, school building, school development, social welfare, special student scholarship fund.

Also Shaanxi province to do better in University Education Foundation are: Educational Foundation of Xi'an Petroleum University, Xi'an University of Science and Technology Education Foundation Architecture, Xi'an University of Science Education Foundation, Education Foundation Xi'an Petroleum University, Yulin Institute of Education Development Fund Council Education Foundation city College of Xi'an Jiaotong University, Xi'an Eurasia University Education development Foundation, the Foundation of Xi'an International University, Xi'an Siyuan University Foundation, and so on. 


\section{The Operating Characteristics of Shaanxi Higher Education Foundation}

According to our investigation of public information Shaanxi Higher Education Foundation website each comprehensive analysis of their operating characteristics are the following five aspects.

Revenue from donations Shaanxi Higher Education Foundation, mostly in public universities, was a significant imbalance. Such as Xi'an Jiaotong University Education Foundation donated revenue of nearly three million more than in 3200, only in May 2014, Zhejiang Fu Li Charitable Foundation has donated 100 million yuan to the Education Foundation of Xi'an Jiaotong University, Xi'an Jiaotong focus for the construction Li Fu University of food Science and Engineering. NPU Foundation in 2012 got only 140 million yuan. The revenue and expenditure fund other general education schools have been small, especially Xi'an Eurasia University Education Development Foundation, the Foundation of Xi'an International University, Xi'an Siyuan University Foundation three private universities are in a non-public offering of identity exist, only Xi'an Jiaotong University Foundation is a public foundation. As can be seen from the above facts, the nature of the effect of different Universities Foundation is different, public foundations and private foundations have advantages and disadvantages, as private foundations is the community public to raise funds, relatively speaking, easier imputation funds ; but not raised funds for universities is also good, fundraising money to spend can take - because "Foundation management regulations" provisions: when expenditure, for private foundations looser restrictions, as long as the spent assets to 8\%, while private foundations will have to spend 70 per cent of last year's income assets. Research group believes Shaanxi data demonstrate that in the early stage of development of University Foundation, the Foundation raised some more interest. From the use of perspective, the use of funds in University Foundation is mainly used for teacher development, teaching and research, research, campus local small construction, environmental protection and energy saving, anniversary and other small projects, which is characterized by the use of a lot of projects and use of funds dispersed funds or effect donations little impact, and this tends to affect the determination of the contributions of entrepreneurs.

Higher Education Foundation of a specialized nature and general management foundation is different from its working set human, social, economic, educational, financial integration, but not purely financial regulatory agencies, it is a complicated systematic project, which work includes all aspects of aspects, such as raising funds, the daily management of the Foundation to fund research direction, fund operations and other value-added, needs marketing, public relations, legal, advertising and other professional background of high-quality professionals. Universities currently set but managed professional colleges set up many educational foundation management professional institutions of higher learning almost nothing, which leads to lack of education is very professional fund management talent. According to our survey, mainly in Shaanxi Education Foundation universities set up as the main body established by a number of other educational foundations accounted for relatively small. Shaanxi 22 educational foundations, institutions of higher learning as the main body established by the Education Foundation for a total of 15, although its employees have a high degree, but they are non-professional veteran, especially in the professional management of the Foundation, funds mobilization extreme shortage of talent, the quality of employees can imagine other types Education Foundation, which led directly to the effects of the operation Education Fund generally not high, such as the Office of Shaanxi Province, preferably educational Foundation College NWAFU Education development Fund It will finance and investment income for 2013 was only 46,308 yuan, accounting for $0.3 \%$ of its annual revenue. The Foundation foreign universities through professional management and operation of capital gains rate of about $10 \%$ or more, even up to $20 \%$ to $30 \%$, can be effective in achieving Education Fund preservation and appreciation. And by most universities in Shaanxi Foundation Foundation Public expenditure management costs do not exceed $10 \%$ of the limit, and less on full-time staff with the Foundation, by a majority of school administrators to work part-time foundation. Part-time staff energy is limited, the lack of sufficient awareness of the work of the Foundation, the initiative work, creative enough, without systematic financing, investment and other specialized training, 
generally low degree of specialization, has seriously affected the financing of private education in Colleges Foundation effectively, let alone take full advantage of the characteristics of capital appreciation, capital operation performed.

Although many private schools in Shaanxi Province, but only Xi'an International University, Xi'an Eurasia University, Xi'an Jiaotong University City College Fund, Xi'an Siyuan University has established education foundation and there are some activities, Xi'an Siyuan University or the National Institute of Higher Education Fund Research will be members of the western alliance. Various private education foundations, although Universities in Shaanxi Province to raise a certain amount of funds for the development of private universities, but on the Education Foundations many problems, mainly in seven areas: the establishment of time is generally short, the number of small initial capital, social donations accounted for a small proportion of school funding, not the size of the net assets of the fund, manage and grow weak, poor website publicity and information disclosure channels, donors not much incentive to carry forward. Shaanxi Education Foundation Private Colleges general initial capital of 300 million or less, the net assets of more than ten million yuan barely. Donations accounted for a small proportion of school funding, no funds amounting to more than 1\%. Fund managers small number of lack of experience, way to much, which leads to either or both the number of fund-raising activities and the effect of the huge gap with foreign universities and public education foundations and universities, such as the Education Foundation of Northwest Polytechnical University, Xi'an Jiaotong University Universities and other public education foundation had net assets of billions of dollars. Social Europe and other countries in the Anglo-German university donated about $10 \%$ of school funding, donations Public Universities in Japan accounted for about $15 \%$ of total income schools, many private schools is as high as $50 \%$. The amount donated US Harvard, Stanford and other elite schools of up to \$ 500 million.

A major problem is to manage the boundaries are not clear, strictly speaking, all types are approved by the Education Foundation Corp. organization set up by the civil affairs departments at all levels of government, rather than by the competent institution or education authority holding shares or corporate organization there is no relationship between the leader and the led organization, but all kinds of Shaanxi province Education Foundation have a lot of administrative management model is based on the main type, can not fully meet the market demand, the majority of university foundations of an administrative type upcoming school functions as a foundation to treat and manage patterns Foundation as an independent judicial person status has not been fully reflected. The direct consequence is not fully mobilize the enthusiasm of the Foundation, the initiative is not enough work, low efficiency, management is not flexible enough and so on. Private University Management Education Foundation also generally kept live another problem is that the organization is not perfect, obviously insufficient staffing, work procrastination, often the foundation of pioneering development work into business school alumni or admissions department responsible for employment, accounting accounting work by the school on behalf of bookkeeping accounting department hosted funded projects selected by the Office of Academic Affairs, student Office or research department responsible for the selection, inadequate internal controls. We believe that, as the College Foundation Corp., should have strict sound organization, with adequate professional management staff. In the number of staff, for example, only the University of California staff responsible for financial operations of the 46 people there, and Harvard, Yale, etc. daily staff American private foundations, there are over a hundred thousand. At present, Shaanxi College Foundation, the organization is not standardized, robust, and full-time professional staff in particular with generally inadequate, seriously affecting the work of the Foundation to carry out and play functions.

China Industry Foundation Center site on University Education Foundation of Shaanxi Province Transparency Index rating is generally low, which is related to the environment in Shaanxi Province, Shaanxi transparency throughout the Foundation only an average of 35.55\%, ranked first in the country 28. But there are good stories, Shaanxi Province, Universities Education Foundation Education Foundation only a Northwest Agricultural University transparency of 100, followed by the transparency of the Foundation 76 Northwestern Polytechnical University, Xi'an Jiaotong 
University Foundation 62.8, which are higher than the national average value. Low transparency of Yulin College Education Foundation 18, Shaanxi Education Foundation is only 5.6 from the national data, the average transparency index was $49.69 \mathrm{FTI}$, ranked first in Zhejiang, transparency index was 70.39. Based on our current statistics Foundation Center CFC analysis, branding Foundation fund-raising ability and the Foundation, the Fund's intended use and so there is a strong correlation with the level of transparency Education Foundation Foundation raising the number is not much correlation between the level of transparency and net assets was the correlation is very low, but we considered the long term, with the improvement of the composition and political consciousness of the donor, the donor will inevitably whereabouts of donated funds, the use of effects, and more concerned about the level of transparency Foundation data directly on the number of donations occurred great influence.

\section{Conclusion}

In summary, we find that, although a lot of education foundation, but the foundation is not much higher education; Universities Foundation absorb a lot of social capital but most took was 985 College Foundation, Colleges and Universities Foundation funds get low share; private colleges and universities accounted for 20 percent of colleges and universities, the share of funding private education Colleges Foundation got minimal. Private Universities of Shaanxi Education Foundation presents donation income and expenditure is very uneven, comparative lack of professional management personnel, the smaller scale of development, organization and management mechanism is not perfect specification, and high transparency is generally not an urgent need to pay attention to colleges and universities, plus Great for the Education Foundation of human, financial investment, and guide professional conduct special studies for the development of private colleges and universities Education Foundation to pave the way.

\section{Acknowledgements}

Shaanxi Provincial Department of Education key scientific research projects, number: 13JZ074, Project Name: Private Colleges and Universities in Shaanxi Investment and Financing Management Mechanism Design Research and Education Foundation was created.

\section{References}

[1] Zhong Chunmei. discuss funding for the Private University Education Foundation [J]. Accounting, 20145

[2] Yu Xiaoying. financing and operation of the Mechanism of Public Social Donation to Universities [N]. Tongji University, a master's degree thesis, $12^{\text {th }}, 2006$. 